\title{
Microstructure and Hot Deformation Behaviour of a Novel Zr-Alloyed High-Boron Steel
}

\author{
Alexey Prosviryakov ${ }^{1, *}$, Baptiste Mondoloni ${ }^{1,2}$, Alexander Churyumov ${ }^{1}$ and \\ Andrey Pozdniakov ${ }^{1}$ \\ 1 National University of Science and Technology "MISiS", Leninskiy Prospekt 4, 119049 Moscow, Russia; \\ baptiste.mondoloni@edf.fr (B.M.); churyumov@misis.ru (A.C.); pozdniakov@misis.ru (A.P.) \\ 2 French electricity supplier "EDF", 86320 Civaux, France \\ * Correspondence: pro.alex@mail.ru; Tel.: +007-495-955-0134
}

Received: 14 January 2019; Accepted: 8 February 2019; Published: 12 February 2019

\begin{abstract}
A novel corrosion-resistant steel with high boron content is investigated in this paper. Three stages during crystallisation of the steel are revealed. The positive influence of $\mathrm{Zr}$ addition on the microstructure and mechanical properties after hot deformation is shown. The $\mathrm{Zr}$-alloyed steel demonstrates hot deformation without fracturing in the temperature range of 1273-1423 K, and in the strain rate range of $0.1-10 \mathrm{~s}^{-1}$, despite the high volume of brittle borides. The processes of ferrite recrystallisation and boride structure fragmentation occur during hot deformation, promoting the appearance of a peak on stress-strain curves.
\end{abstract}

Keywords: high-boron steel; high-speed steel; hot deformation; mechanical properties; borides

\section{Introduction}

Stainless steels with high boron content (more than $1.2 \mathrm{wt}$. \%) are important materials for the production of spent nuclear fuel storage due to the high neutron-absorbing capacity of boron $[1,2]$. Conversion of the nuclear power plants to more enriched fuel requires improved neutron-absorbing capacity of the materials. As a result, new high-boron steels with a boron concentration more than $3 \mathrm{wt}$. $\%$ are required to guarantee the safety and efficiency of spent nuclear fuel storage. This type of material is also very attractive for application as a high-speed steel, due to a high degree of hardness and good wear resistance of the borides [3,4]. However, the low technological plasticity of high-boron steels limits their applications because of the high costs of their production. In this case, the preliminary investigation of the microstructure and deformation behaviour of hard deformable steels is required to develop improved industrial technologies. In most cases, the deformation behaviour is investigated by mechanical tests using thermomechanical simulators, followed by the development of constitutive models [5-7] and processing maps [8,9], which are the power instruments for finding the optimal deformation conditions. Besides, the addition of the steel by the borides forming elements such as Ti and $\mathrm{Zr}$ may have a positive influence on the microstructure. Titanium forms $\mathrm{TiB}_{2}$ phase which contains $1.40 \mathrm{~g} / \mathrm{cm}^{3}$ of boron in comparison with $\approx 0.68 \mathrm{~g} / \mathrm{cm}^{3}$ for $(\mathrm{Cr}, \mathrm{Fe})_{2} \mathrm{~B}$. It decreases the amount of brittle phases in a high-boron steel microstructure $[10,11]$. He et al. showed that Ti improves the strength and plasticity of the binary Fe-B alloys after hot deformation $[12,13]$. The purpose of our work is to investigate the microstructure and hot deformation behaviour of a novel $\mathrm{Zr}$-alloyed stainless steel with high boron content.

\section{Materials and Methods}

An alloy with the nominal composition of $\mathrm{Fe}-16 \mathrm{Cr}-4 \mathrm{Ti}-6 \mathrm{Zr}-3.2 \mathrm{~B}$ (wt \%) was produced by arc melting of pure $\mathrm{Fe}, \mathrm{Cr}$, Ti and $\mathrm{Zr}$ metals and $\mathrm{Fe}-17 \mathrm{wt}$. \% B master alloy in an argon atmosphere. 
After remelting had been undertaken four times, the samples were produced by casting into a copper mould with a diameter of $12.7 \mathrm{~mm}$. Investigation of the alloy microstructure was performed by scanning electron microscopy (SEM) and by X-ray diffraction (XRD). The mean size of the particles was measured by a linear intercept method. For each sample, 3-5 different $50 \times 40 \mu^{2}$ regions were analyzed. Compression tests were performed using a Gleeble 3800 thermomechanical simulator. The specimens for the compression tests, with a diameter of $10 \mathrm{~mm}$ and a height of $15 \mathrm{~mm}$, were heated to the deformation temperature (1273-1423 K) and compressed to one true strain at $0.1,1$ and $10 \mathrm{~s}^{-1}$ constant true strain rates. Compression tests at room temperature were carried out on cylindrical specimens (6 $\mathrm{mm}$ in height and $4 \mathrm{~mm}$ in diameter) cut from the hot compressed samples. Melting and solidification temperatures of the alloy were measured by differential thermal analysis (DTA) at the heating and cooling rate of $0.33 \mathrm{~K} / \mathrm{s}$. Accelerated corrosion test [14] was applied to the investigated steel and for comparison to the industrial steel Fe-14Cr-5Ti-0.3V-1.8B (ChS-82) which is most common for production of spent nuclear fuel storage. The samples with the size of $12.7 \mathrm{~mm}$ in diameter and $1 \mathrm{~mm}$ in width were held 5 and $24 \mathrm{~h}$ in the $10 \% \mathrm{FeCl}_{3} \cdot 6 \mathrm{H}_{2} \mathrm{O}$ water solution. After the holding, the mass loss rate was calculated according to the formula:

$$
V_{m}=\frac{\Delta m}{S t}
$$

where $\Delta m$ is a lost mass, $\mathrm{g}$; $S$ is specimen area, $\mathrm{m}^{2} ; t$ is time of the corrosion test, hours.

\section{Results and Discussion}

As shown in Figure 1, the microstructure of as-cast steel consists of $\alpha(\mathrm{Fe})$ solid solution and three types of borides: black particles of $\mathrm{TiB}_{2}$, grey eutectic colonies of $(\mathrm{Cr}, \mathrm{Fe})_{2} \mathrm{~B}$ and white particles of $\mathrm{ZrB}_{2}$. Usually, the structure of Ti-doped steel with a high boron concentration contains large $\mathrm{TiB}_{2}$ particles with an irregular shape [15]. $\mathrm{Zr}$ addition strictly decreases the volume fraction of these particles. As one can see in Figure 1a, few large $\mathrm{TiB}_{2}$ particles are present in the microstructure. $\mathrm{Zr}$ also has a positive influence on the size of the $\alpha(\mathrm{Fe})-(\mathrm{Cr}, \mathrm{Fe})_{2} \mathrm{~B}$ eutectic colonies due to a modifying effect [16]. The average size of the borides is presented in Table 1.
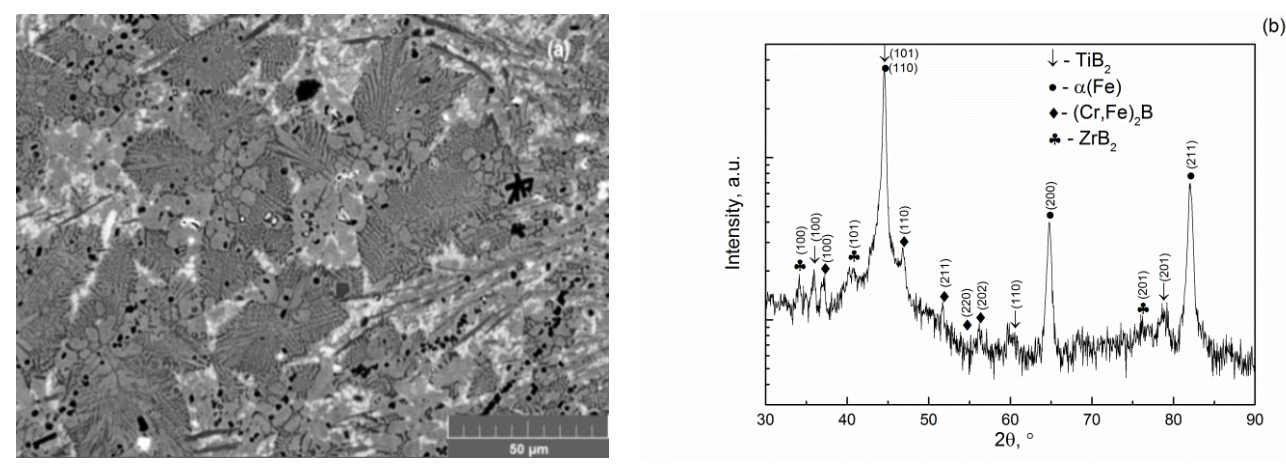

Figure 1. As-cast microstructure (SEM) of the investigated steel (a) and XRD pattern (b).

Table 1. The size of the borides in the as-cast state and after hot deformation (HD).

\begin{tabular}{cccc}
\hline \multirow{2}{*}{ State } & \multicolumn{3}{c}{ Average Size of the Particles, $\boldsymbol{\mu m}$} \\
\cline { 2 - 4 } & $\mathbf{T i B}_{\mathbf{2}}$ & $\mathbf{( C r , F e})_{\mathbf{2}} \mathbf{B}$ & $\mathbf{Z r B}_{\mathbf{2}}$ \\
\hline As-cast & $3 \pm 1$ & $0.7 \pm 0.2$ & $2 \pm 0.6$ \\
\hline HD 1373 K, $1 \mathrm{~s} \mathrm{~s}^{-1}$ & $2 \pm 0.5$ & $0.5 \pm 0.1$ & $1.8 \pm 0.6$ \\
\hline HD 1373 K, $10 \mathrm{~s}^{-1}$ & $1.5 \pm 0.5$ & $0.4 \pm 0.1$ & $1.4 \pm 0.4$ \\
\hline HD 1423 K, $1 \mathrm{~s} \mathrm{~s}^{-1}$ & $1.2 \pm 0.3$ & $0.5 \pm 0.1$ & $1 \pm 0.3$ \\
\hline HD 1423 K, $10 \mathrm{~s}^{-1}$ & $1.1 \pm 0.3$ & $0.6 \pm 0.1$ & $1 \pm 0.2$ \\
\hline
\end{tabular}


As can be seen in Figure 2a, the liquidus and solidus temperatures of the steel are $1530 \mathrm{~K}$ and $1490 \mathrm{~K}$, respectively. The exothermal crystallisation peak may be separated into three peaks (Figure 2b). Each of the peaks corresponds to a different crystallisation reaction. The high temperature peak corresponds to the reaction of the crystallisation of $\mathrm{ZrB}_{2}+\alpha(\mathrm{Fe})$ from the liquid phase, which can be proven by the absence of the high temperature peak in the DTA curve of the alloy without Zr [17]. The reaction $\mathrm{L} \rightarrow \mathrm{TiB}_{2}+\alpha(\mathrm{Fe})$ leads to the exothermic effect seen in the second peak. The last peak corresponds to the eutectic crystallisation of $\left((\mathrm{Cr}, \mathrm{Fe}){ }_{2} \mathrm{~B}+\alpha(\mathrm{Fe})\right)$.
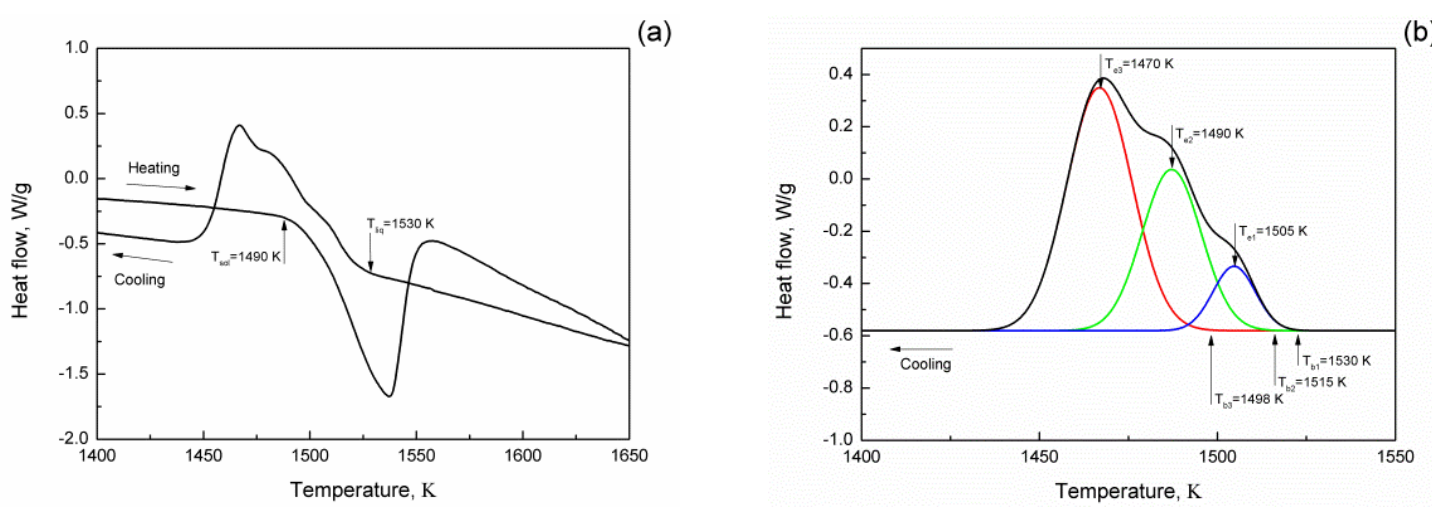

Figure 2. DTA curves (a) and crystallisation peak analysis (b) of the investigated alloy.

The maximal deformation temperature of the alloy of $1423 \mathrm{~K}$ was chosen according to the DTA to prevent the melting of the sample during the compression test from adiabatic heating. As one can see in Figure 3, the hot compression of the Fe-16Cr-4Ti-6Zr-3.2B steel proceeds without fractures in the temperature range of $1273-1423 \mathrm{~K}$, and in the strain rate range of $0.1-10 \mathrm{~s}^{-1}$. As shown in Figure 4 , the stress is increased with the increase of the strain rate and decrease of the deformation temperature. True stress achieves its maximal value at low strains during compression for all temperatures and strain rates. It is known $[18,19]$ that peak strain $\left(\varepsilon_{\mathrm{p}}\right)$ can be expressed as a power-law function of the Zener-Hollomon parameter $Z=\dot{\varepsilon} \exp \left(\frac{Q}{R T}\right)[20]$ as given by:

$$
\varepsilon_{\mathrm{P}}=A Z^{\mathrm{m}}=A\left[\dot{\varepsilon} \exp \left(\frac{\mathrm{Q}}{\mathrm{RT}}\right)\right]^{m}
$$

where $\dot{\varepsilon}$ is a strain rate, $\mathrm{s}^{-1} ; T$ is a temperature, $\mathrm{K} ; R$ is a universal gas constant, $A ; m$ and $Q$ are the constants determined by least squares method using experimental data and linearized Equation (2):

$$
\ln \varepsilon_{\mathrm{P}}=\ln A+m \ln \varepsilon+\frac{m Q}{\mathrm{RT}}
$$

So, the ep can be calculated by the follow equation:

$$
\varepsilon_{\mathrm{P}}=0.001 Z^{0.22}=0.001\left[\dot{\varepsilon} \exp \left(\frac{3,4900}{\mathrm{RT}}\right)\right]^{0.22}\left(\mathrm{R}^{2}=0.81\right),
$$

where $\dot{\varepsilon}$ is the strain rate $\left(\mathrm{s}^{-1}\right)$ and $T$ is the deformation temperature $(\mathrm{K})$. After reaching the peak strain rate, the processes of fragmentation of the boride colonies and the dynamic recrystallisation begins (Figure 5), leading to a significant decrease in the true stress (Figure 4). The steady state deformation proceeds after $0.5-0.6$ of true stress, depending on the temperature and the strain rate. As shown in Figure 5 and Table 1, the size of the $\mathrm{ZrB}_{2}$ and $\mathrm{TiB}_{2}$ borides is decreased after hot deformation has occurred. An increase of the deformation temperature decreases the size of these particles. Contrariwise, the size of the $(\mathrm{Cr}, \mathrm{Fe})_{2} \mathrm{~B}$ is not decreased during the deformation due to the initial small size of the eutectic colonies. As shown in Figure $6 b, c$, the microstructure of the steel after 
hot deformation at the temperature of $1373 \mathrm{~K}$ and at the strain rate $1 \mathrm{~s}^{-1}$ and at the temperature of $1423 \mathrm{~K}$ and at the strain rate $10 \mathrm{~s}^{-1}$ consists mainly of small recrystallised grains, whereas in the phase composition of the steel did not change significantly after the hot compression (Figure 6c).

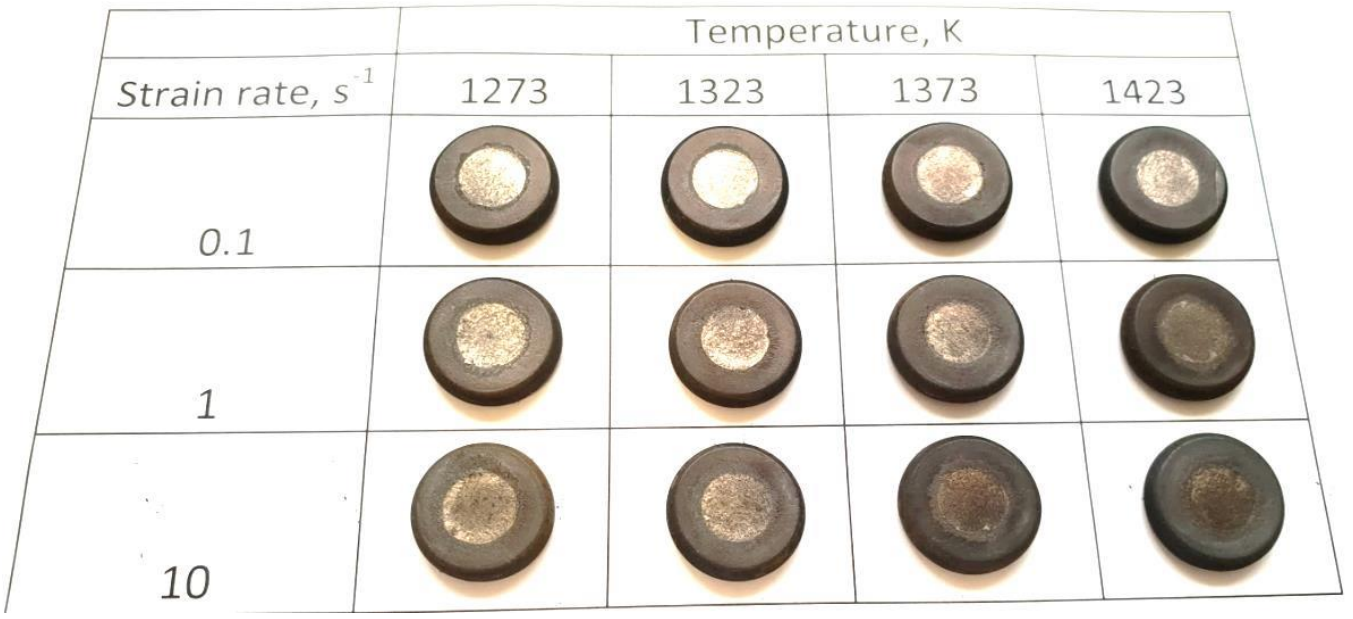

Figure 3. The images of the samples after hot deformation.

(a)
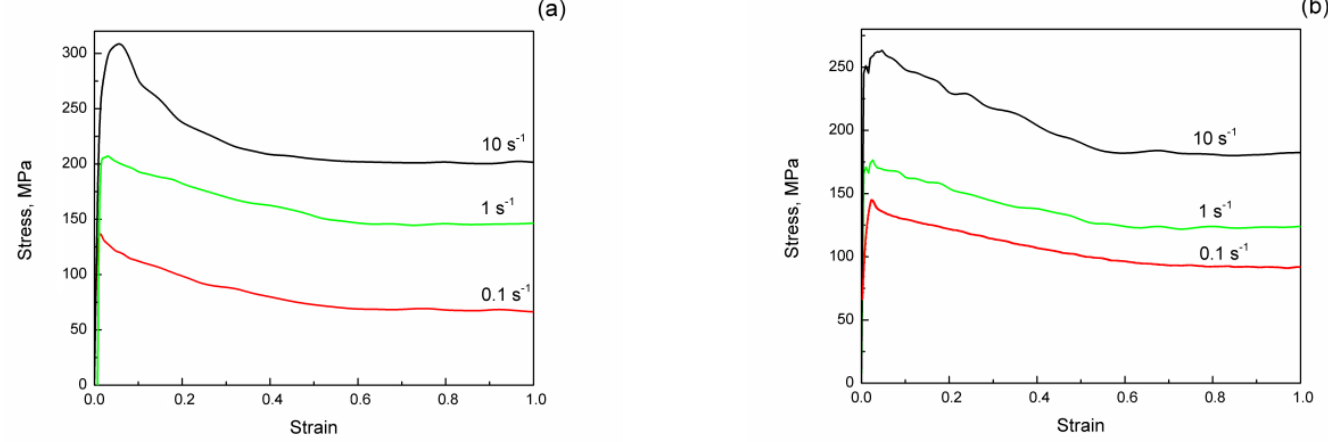

(c)

(d)
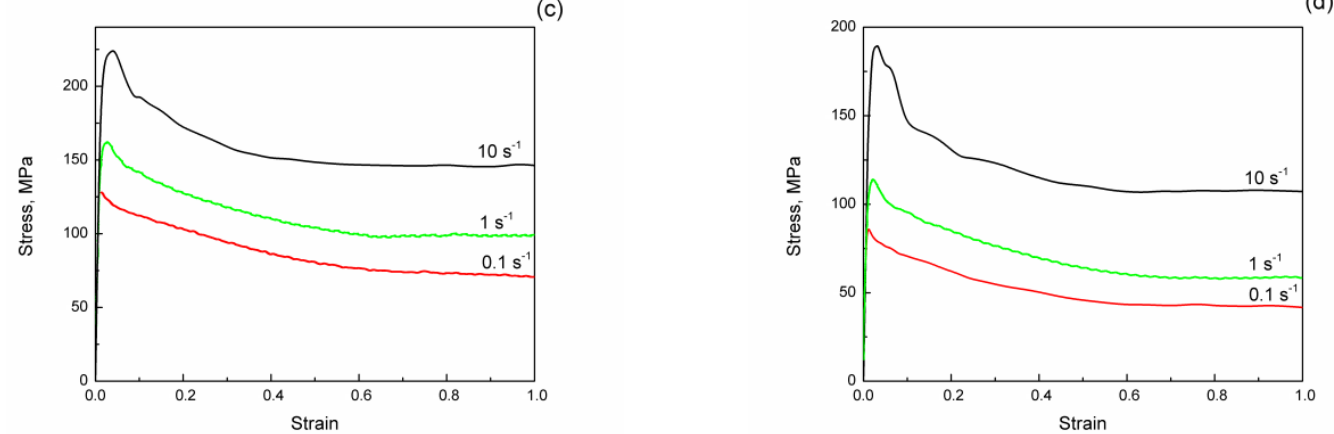

Figure 4. Stress-strain curves of the Fe-16Cr-4Ti-6Zr-3.2B steel at temperatures of $1273 \mathrm{~K}(\mathbf{a}), 1323 \mathrm{~K}$ (b), $1373 \mathrm{~K}(\mathbf{c})$ and $1423 \mathrm{~K}(\mathbf{d})$. 

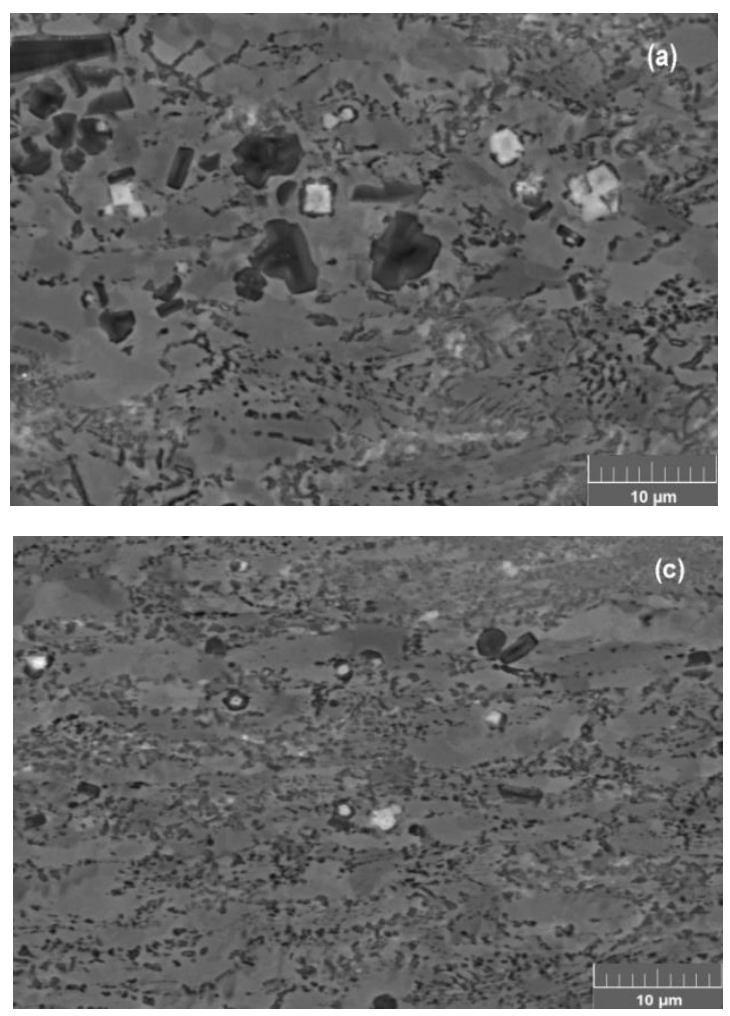
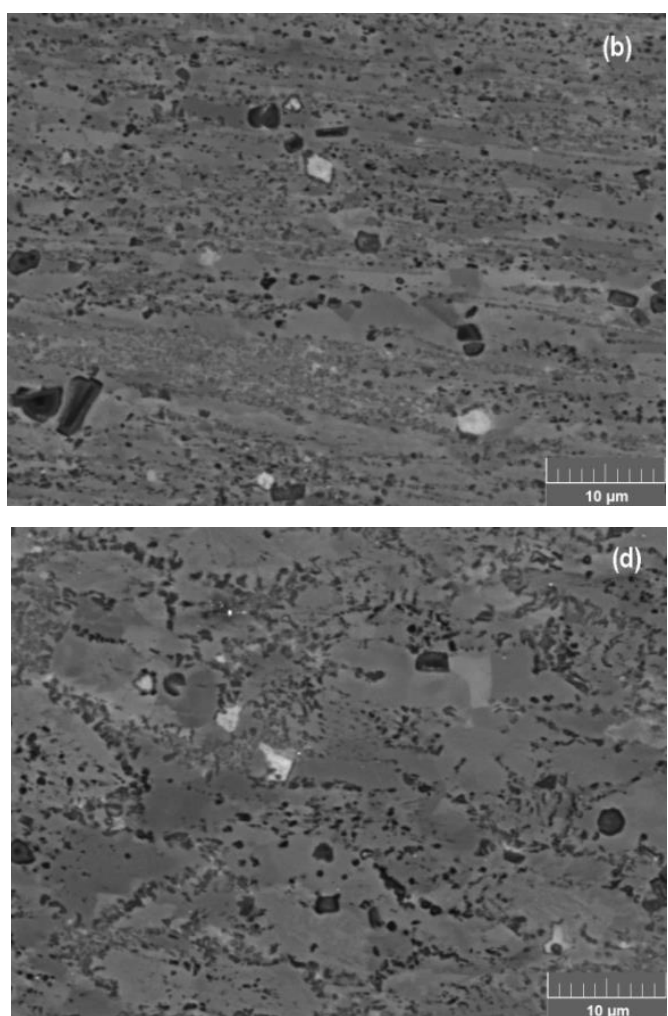

Figure 5. Microstructure of the $\mathrm{Fe}-16 \mathrm{Cr}-4 \mathrm{Ti}-6 \mathrm{Zr}-3.2 \mathrm{~B}$ steel after hot deformation: $1373 \mathrm{~K}, 1 \mathrm{~s}^{-1}$ (a); $1373 \mathrm{~K}_{1} 10 \mathrm{~s}^{-1}$ (b); $1423 \mathrm{~K}, 1 \mathrm{~s}^{-1}$ (c); $1423 \mathrm{~K}, 10 \mathrm{~s}^{-1}$ (d).

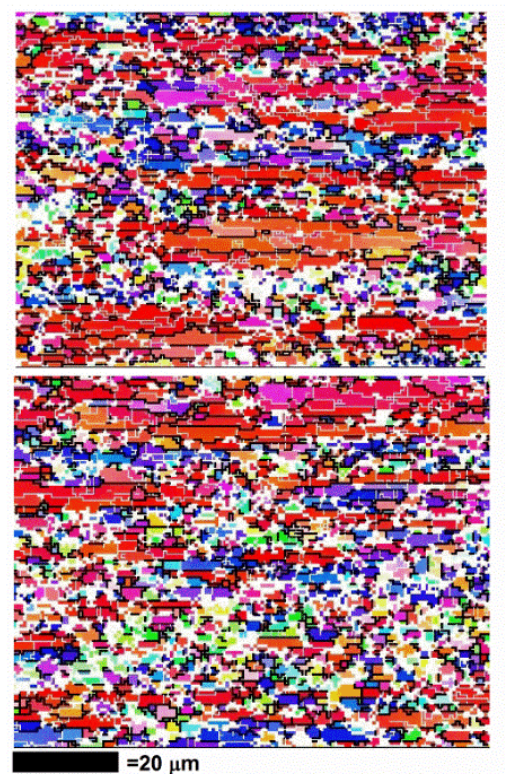

(a)

Figure 6. EBSD maps of the steel after hot compression at the temperature of $1373 \mathrm{~K}$ and at the strain rate $1 \mathrm{~s}^{-1}(\mathbf{a})$, at the temperature of $1423 \mathrm{~K}$ and at the strain rate $10 \mathrm{~s}^{-1}(\mathbf{b})$ and XRD patterns of the steel after deformation (c).

Room temperature compression stress-strain curves of the investigated steel after hot deformation are presented in Figure 7. Steel demonstrates a high degree of strength and good plasticity after hot deformation at temperatures in the range of $1273-1423 \mathrm{~K}$, and at strain rates in the range of 1-10 s ${ }^{-1}$. The decrease of the strain rate to $0.1 \mathrm{~s} \mathrm{~s}^{-1}$ decreases the yield stress of the steel on 50-150 MPa in comparison with higher strain rates. 


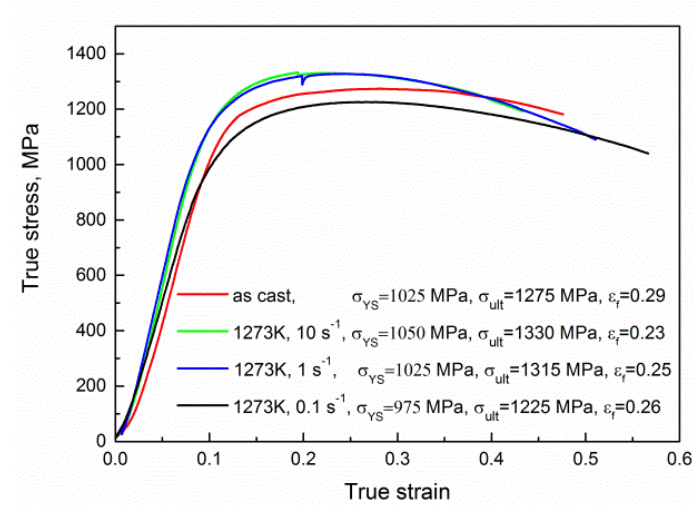

(a)

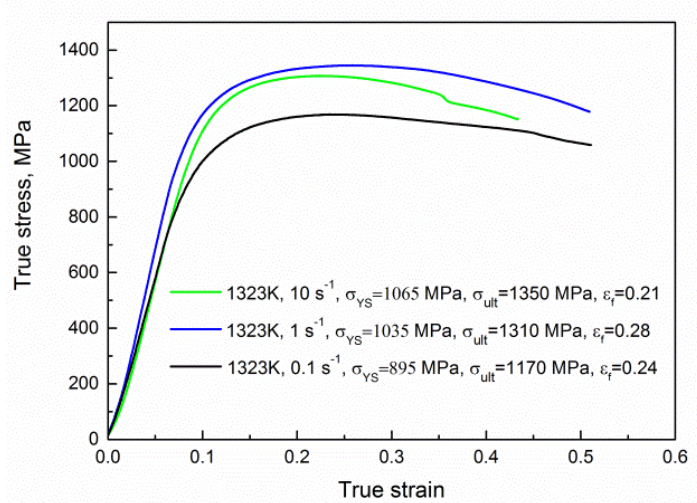

(b)

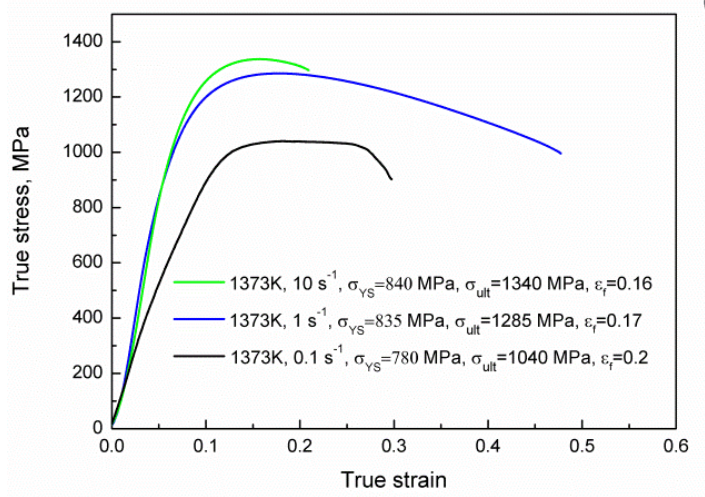

(c)

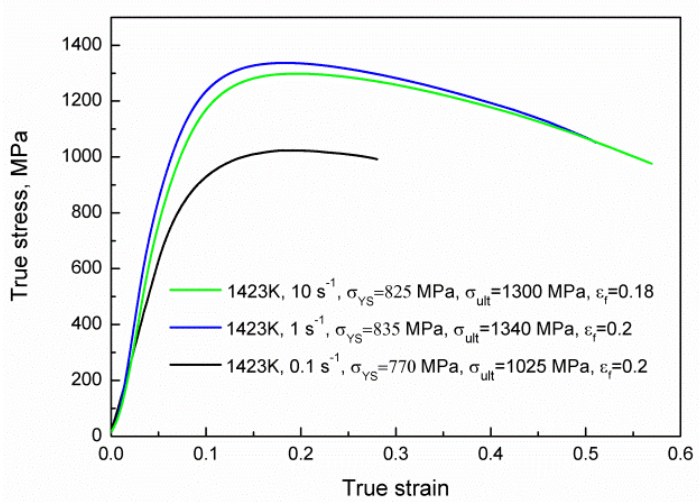

(d)

Figure 7. Mechanical properties of the investigated steel after hot deformation.

The images of the specimens before and after corrosion test are shown in Figure 8 . As one can see, the $\mathrm{Fe}-16 \mathrm{Cr}-4 \mathrm{Ti}-6 \mathrm{Zr}-3.2 \mathrm{~B}$ steel is more resistive to aggressive $\mathrm{Cl}^{-}$-contained environment than $\mathrm{Fe}-14 \mathrm{Cr}-5 \mathrm{Ti}-0.3 \mathrm{~V}-1.8 \mathrm{~B}$ steel due to a higher concentration of the alloying elements such as $\mathrm{Cr}$, Ti and $\mathrm{Zr}$. The mass loss rate for the investigated steel is $25 \mathrm{~g} /\left(\mathrm{m}^{2} \cdot \mathrm{h}\right)$. It is more than twice smaller than the mass loss rate for Fe-14Cr-5Ti-0.3V-1.8B steel with $V_{\mathrm{m}}=57 \mathrm{~g} /\left(\mathrm{m}^{2} \cdot \mathrm{h}\right)$.

0 hours

Fe-16Cr-4Ti

$-6 \mathrm{Zr}-3.2 \mathrm{~B}$

steel

Fe-14Cr-5Ti

$-0.3 \mathrm{~V}-1.8 \mathrm{~B}$

steel
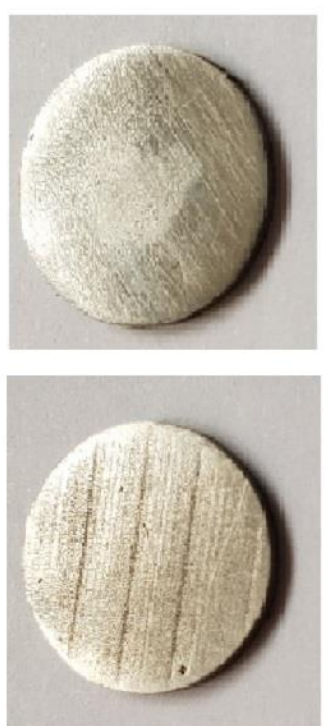

5 hours
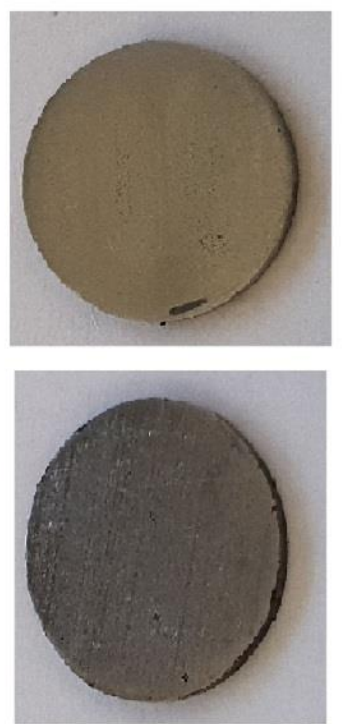

24 hours
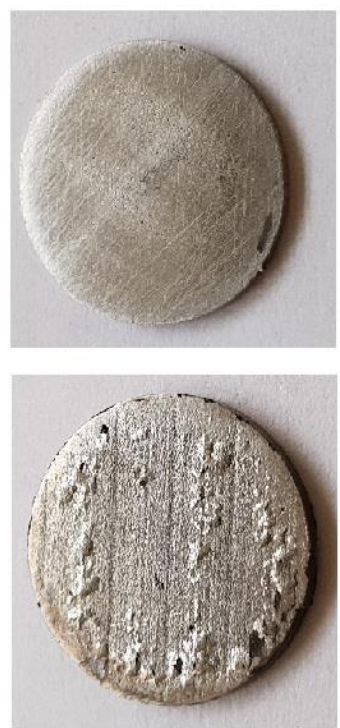

Figure 8. Images of the specimens before and after accelerated corrosion test in the $10 \% \mathrm{FeCl}_{3} \cdot 6 \mathrm{H}_{2} \mathrm{O}$ water solution. 
The fine microstructure, good mechanical properties, satisfactory corrosion resistance and possibilities for applications of hot plastic deformation without fractures despite the presence of a large volume of brittle borides make the investigated alloy attractive as a high-speed steel and to the nuclear industry.

\section{Conclusions}

1. The phases of $\alpha(\mathrm{Fe}), \mathrm{ZrB}_{2}, \mathrm{TiB}_{2}$ and $(\mathrm{Cr}, \mathrm{Fe})_{2} \mathrm{~B}$ are formed in the microstructure during three-stage crystallisation of the $\mathrm{Fe}-16 \mathrm{Cr}-4 \mathrm{Ti}-6 \mathrm{Zr}-3.2 \mathrm{~B}$ steel.

2. The hot compression of the $\mathrm{Fe}-16 \mathrm{Cr}-4 \mathrm{Ti}-6 \mathrm{Zr}-3.2 \mathrm{~B}$ steel proceeds without fractures in the temperature range of $1273-1423 \mathrm{~K}$ and in the strain rate range of $0.1-10 \mathrm{~s}^{-1}$. Hot deformation leads to fragmentising of the eutectic structure and a decrease in the size of the $\mathrm{ZrB}_{2}$ and $\mathrm{TiB}_{2}$ particles.

3. True stress-true strain curves show nonmonotonic behaviour with the achievement of peak stress, followed by boride fragmentation and $\alpha(\mathrm{Fe})$ dynamic recrystallisation processes. The peak strain value depends on the Zener-Hollomon parameter by power low:

$$
\varepsilon_{\mathrm{P}}=0.001 Z^{0.22} .
$$

4. The investigated alloy possesses a high yield strength of $825-840 \mathrm{MPa}$, and good plasticity of $0.16-0.2$, after hot deformation in the range of 1373-1423 K.

5. Corrosion resistance of the novel $\mathrm{Zr}$-alloyed high-boron steel in the aggressive $\mathrm{Cl}^{-}$-contained environment is better than corrosion resistance of the industrial Fe-14Cr-5Ti-0.3V-1.8B steel, which is currently most common for production of spent nuclear fuel storage.

Author Contributions: Conceptualization, A.P.(Alexey Prosviryakov) and A.C.; investigation, B.M. and A.P.(Andrey Pozdniakov); writing—original draft preparation, A.C.; writing-review and editing, A.P.(Alexey Prosviryakov); funding acquisition, A.C.

Funding: This work was supported by the Russian Science Foundation (project No. 18-79-10153).

Conflicts of Interest: The authors declare no conflict of interest.

\section{References}

1. Churyumov, A.Y.; Khomutov, M.G.; Tsar'kov, A.A.; Pozdnyakov, A.V.; Solonin, A.N.; Efimov, V.M.; Mukhanov, E.L. Study of the structure and mechanical properties of corrosion-resistant steel with a high concentration of boron at elevated temperatures. Phys. Met. Metallogr. 2014, 115, 809-813. [CrossRef]

2. Shulga, A.V. A comparative study of the mechanical properties and the behavior of carbon and boron in stainless steel cladding tubes fabricated by PM HIP and traditional technologies. J. Nucl. Mater. 2013, 434, 133-140. [CrossRef]

3. Ma, S.; Xing, J.; Guo, S.; Bai, Y.; Fu, H.; Lyu, P.; Huang, Z.; Chen, W. Microstructural evolution and mechanical properties of the aluminum-alloyed Fe-1.50 wt \% B- $0.40 \mathrm{wt} \%$ C high-speed steel. Mater. Chem. Phys. 2017, 199, 356-369. [CrossRef]

4. Ma, S.; Pan, W.; Xing, J.; Guo, S.; Fud, H.; Lyu, P. Microstructure and hardening behavior of Al-modified Fe-1.5 wt \% B-0.4 wt \% C high-speed steel during heat treatment. Mater. Charact. 2017, 132, 1-9. [CrossRef]

5. Yin, F.; Hua, L.; Mao, H.; Han, X. Constitutive modeling for flow behavior of GCr15 steel under hot compression experiments. Mater. Des. 2013, 43, 393-401. [CrossRef]

6. Churyumov, A.Y.; Khomutov, M.G.; Solonin, A.N.; Pozdniakov, A.V.; Churyumova, T.A.; Minyaylo, B.F. Hot deformation behaviour and fracture of $10 \mathrm{CrMoWNb}$ ferritic-martensitic steel. Mater. Des. 2015, 74, 44-54. [CrossRef]

7. Zou, D.; Wu, K.; Han, Y.; Zhang, W.; Cheng, B.; Qiao, G. Deformation characteristic and prediction of flow stress for as-cast 21Cr economical duplex stainless steel under hot compression. Mater. Des. 2013, 51, 975-982. [CrossRef] 
8. Anoop, C.R.; Prakash, A.; Giri, S.K.; Narayana Murty, S.V.S.; Samajdar, I. Optimization of hot workability and microstructure control in a $12 \mathrm{Cr}-10 \mathrm{Ni}$ precipitation hardenable stainless steel: An approach using processing maps. Mater. Charact. 2018, 141, 97-107. [CrossRef]

9. Kishor, B.; Chaudhari, G.P.; Nath, S.K. Hot workability of $16 \mathrm{Cr}-5 \mathrm{Ni}$ stainless steel using constitutive equation and processing map. Mater. Today: Proc. 2018, 5, 17213-17222. [CrossRef]

10. Ren, X.; Fu, H.; Xing, J.; Yi, Y. Effect of solidification rate on microstructure and toughness of Ca-Ti modified high boron high speed steel. Mater. Sci. Eng. A 2019, 742, 617-627. [CrossRef]

11. Churyumov, A.Y.; Khomutov, M.G.; Pozdnyakov, A.V.; Mukhanov, E.L. Study of the structure and high-temperature mechanical properties of a steel with an elevated content of boron. Met. Sci. Heat. Treat. 2014, 56, 336-338. [CrossRef]

12. He, L.; Liu, Y.; Li, J.; Li, B. Effects of hot rolling and titanium content on the microstructure and mechanical properties of high boron Fe-B alloys. Mater. Des. 2012, 36, 88-93. [CrossRef]

13. Liu, Y.; Li, B.; Li, J.; He, L.; Gao, S.; Nieh, T.G. Effect of titanium on the ductilization of Fe-B alloys with high boron content. Mater. Lett. 2010, 64, 1299-1301. [CrossRef]

14. Russian Standard GOST 9.912-89. Unified System of Corrosion and Aging Protection. Corrosion-Resistant Steels and Alloys. Method of Accelerated Tests for Resistance to Pitting Corrosion; Izdatelstvo Standartov: Moscow, Russia, 1990.

15. Cha, L.; Lartigue-Korinek, S.; Wallsand, M.; Mazerolles, L. Interface structure and chemistry in a novel steel-based composite Fe-TiB2 obtained by eutectic solidification. Acta Mater. 2012, 60, 6382-6389. [CrossRef]

16. Mahmutovich, A.; Nagode, A.; Rimach, M.; Mujagich, D. Modification of the inclusions in austenitic stainless steel by adding tellurium and zirconium. Mater. Tech. 2017, 51, 523-528.

17. Antoni-Zdziobek, A.; Gospodinova, M.; Bonnet, F.; Hodaj, F. Solidification paths in the iron-rich part of the Fe-Ti-B ternary system. J. Alloys Compd. 2016, 657, 302-312. [CrossRef]

18. Sun, W.; Lu, C.; Tieu, A.K.; Jiang, Z.; Liu, X.; Wang, G. Influence of Nb, V and Ti on peak strain of deformed austenite in Mo-based micro-alloyed steels. J. Mater. Proces. Tech. 2002, 125-126, 72-76. [CrossRef]

19. Gong, B.; Duan, X.W.; Liu, J.S.; Liu, J.J. A physically based constitutive model of As-forged 34 CrNiMo6 steel and processing maps for hot working. Vacuum 2018, 155, 345-357. [CrossRef]

20. Zener, C.; Hollomon, J.H. Effect of strain rate upon plastic flow of steel. J. Appl. Phys. 1944, 15, $22-32$. [CrossRef]

(C) 2019 by the authors. Licensee MDPI, Basel, Switzerland. This article is an open access article distributed under the terms and conditions of the Creative Commons Attribution (CC BY) license (http:/ / creativecommons.org/licenses/by/4.0/). 